\title{
LÄMPÖTILAN, VALAISTUKSEN JA KASVUTIHEYDEN VAIKUTUS JAUHOSAVIKAN (CHENOPODIUM ALBUM L.) SATOON.
}

\author{
Leila-Rirtta ERviö \\ Helsingin yliopiston kasvinviljelytieteen laitos
}

Saapunut 30. 5. 1972

\begin{abstract}
THE EFFECT OF TEMPERATURE, LIGHT INTENSITY AND PLANT DENSITY ON THE YIELD OF CHENOPODIUM ALBUM L.
\end{abstract}

LeILA-RittTa ERviö

Institute of Plant Husbandry, University of Helsinki

\begin{abstract}
Pot experiments were carried out in phytotrons under day $(20 \mathrm{~h})$ - night $(4 \mathrm{~h})$ temperatures of $24^{\circ}, 24^{\circ}-14^{\circ}, 12^{\circ}$ and $12^{\circ}-7^{\circ} \mathrm{C}$ and light intensities of 16000 and 5000 lux. Chenopodium album was grown in pots at densities of 50, 100, 200, 400, 800, 1600 and 3200 plants per $\mathrm{m}^{2}$. The plants developed faster at the high temperatures $\left(24^{\circ}, 24^{\circ}-\right.$ $\left.14^{\circ} \mathrm{C}\right)$ than at the low temperatures $\left(12^{\circ}, 12^{\circ}-7^{\circ} \mathrm{C}\right)$. Branching was scarcer at high than at low temperatures. The leaf area index (LAI) was lowest for plants grown at $24^{\circ}$, slightly higher at $24^{\circ}-14^{\circ}$, at its highest at $12^{\circ}$, and fell again slightly in those grown at $12^{\circ}-7^{\circ} \mathrm{C}$. The dry matter yield was smaller at the high than at the low temperatures.

The light intensity of 16000 lux gave rise to faster plant development and higher numbers of branches per plant than that of 5000 lux. The low light produced leaves with a larger specific leaf area (area in relation to weight) than the leaves grown in the bright light. The total yield of plants was considerably higher but the leaves fraction proportionally smaller at 16000 than at 5000 lux.

A steep reduction in the number of branches per plant was found when the growing density was increased from 50 to 400 plants per $\mathrm{m}^{2}$. In the same range of density the LAI increased sharply, but with more than 400 plants per $\mathrm{m}^{2}$ the increase slowed down. Temperature and light intensity had notable effects on the growth model showing the variations in yield of $C$. album at increasing plant densities (Figs. 3-5). Under conditions where the plants remained small the increase in yield was linear, whereas under conditions of strong vegetative growth the yield increases became smaller in dense populations due to competition between individuals.
\end{abstract}

\section{Johdanto}

Helsingin yliopiston kasvinviljelytieteen laitoksella suoritetuissa tutkimuksissa (ERvıö 1972) on aikaisemmin selvitetty lämpötilan ja kasvuston tiheyden vaikutusta jauhosavikan satokäyrään kasvuajan puitteissa. Kun kasvuston tiheydellä ja lämpötilalla osoittautui olevan selvä vaikutuksensa satokäyrän muotoon, tutkimuksia jatkettiin vuonna 1971 . Tällöin pyrittiin selvittämään, millaiseksi muodostuisi sadon kehittymistä tihenevässä kasvustossa esittävä kuvaaja erilaisissa lämpötiloissa valon intensiteetin ollessa erilainen. 
Valaistuksen voimakkuuden on nimittäin todettu vaikuttavan kasvien kuiva-ainesadon määrään (WENT 1957). Kasvutiheyden lisääntyminen taas on eräissä kenttäkokeissä aiheuttanut soijapavun (WIGgANs 1939) ja jauhosavikan (ERvıö 1971) sadon lisääntymisen tiettyyn tiheyteen saakka, minkä jälkeen sadon muutokset ovat olleet vähäisiä, vaikka yksilömäärä pinta-alayksiköllä lisääntyi edelleen.

\section{Tutkimusaineisto ja -menetelmät}

Tutkimukset suoritettiin astiakokeina fytotroneissa, joissa lämpötilat olivat seuraavat:
1) $24^{\circ} \mathrm{C}$ ympäri vuorokauden
2) $24^{\circ} \mathrm{C}$ päivällä $(20 \mathrm{t}), 14^{\circ} \mathrm{C}$ yöllä $(4 \mathrm{t})$
3) $12^{\circ} \mathrm{C}$ ympäri vuorokauden
4) $12^{\circ} \mathrm{C}$ päivällä $(20 \mathrm{t}), 7^{\circ} \mathrm{C}$ yöllä $(4 \mathrm{t})$.

Valaistuksen voimakkuudeksi kasvien korkeudella säädettiin 16000 ja 5000 luxia muuttamalla kasvien etäisyyttä valonlähteestä.

Kasvatusastiat ja kasvualustat olivat samanlaiset kuin aikaisemmin selostetuissa fytotronikokeissa (ERVıö 1972). Astioihin kylvettiin jauhosavikoita kolmena kerranteena seuraavat määrät:

\begin{tabular}{|c|c|c|c|c|}
\hline \multicolumn{3}{|c|}{$\mathrm{kpl}$ vastaten } & \multicolumn{2}{|c|}{50 yksilöä/m² } \\
\hline 2 & " & " & 100 & , \\
\hline 4 & " & , & 200 & , \\
\hline 8 & , & , & 400 & " \\
\hline 16 & , & , & 800 & , \\
\hline 32 & , & , & 1600 & " \\
\hline 64 & " & , & 3200 & ", \\
\hline
\end{tabular}

Tarkoitus oli korjata kasvit siementen kehittymisvaiheessa. Näin meneteltiinkin lämpötiloissa $24^{\circ}$ ja $24^{\circ}-14^{\circ} \mathrm{C}$ kasvaneelle sadolle, mutta $12^{\circ}$ ja $12^{\circ}-7^{\circ} \mathrm{C}$ :n lämpötiloissa jauhosavikoihin ei alkanut kehittyä siemeniä, vaan kasvit osoittivat lakastumisen oireita kukkimisensa jälkeen. Sen vuoksi ne jouduttiin korjaamaan kukinnan päätyttyä. Korjattaessa punnittiin kasvien kuiva-ainesato sekä määritettiin lehtisadon osuus ja lehtien pinta-ala.

\section{Tulokset}

Lämpötilan vaikutus. Alhainen lämpötila hidasti jauhosavikan kehitystä. Esimerkiksi kukinta alkoi $12^{\circ}$ ja $12^{\circ}-7^{\circ} \mathrm{C}$ :ssa noin kaksi kuukautta myöhemmin kuin korkeammissa $\left(24^{\circ}, 24^{\circ}-14^{\circ} \mathrm{C}\right)$ koelämpötiloissa. Sitäpaitsi jauhosavikan reproduktiivinen kehitys estyi kokonaan $12^{\circ}$ ja $12^{\circ}-7^{\circ} \mathrm{C}$ :ssa. Kukinnan päätyttyä kasvit alkoivat näissä lämpötiloissa kuihtua muodostamatta siemeniä.

Jauhosavikkayksilöt haarautuivat runsaammin alhaisissa kuin korkeissa koelämpötiloissa:

$\begin{array}{lc} & \left.\text { Haaroja kpl/yksilö }{ }^{1}\right) \\ 24^{\circ} \mathrm{C} & 3.5^{\mathrm{a}} \\ 24^{\circ}-14^{\circ} \mathrm{C} & 3.6^{\mathrm{a}} \\ 12^{\circ} \mathrm{C} & 8.2^{\mathrm{c}} \\ 12^{\circ}-7^{\circ} \mathrm{C} & 7.2^{\mathrm{b}}\end{array}$

1) Samalla yläindeksillä merkityt luvut eivät poikkea toisistaan $0.05: \mathrm{n}$ varmuudella. 
Ympäri vuorokauden vallinnut $12^{\circ} \mathrm{C}$ :n lämpötila osoittautui haarojen muodostumiselle edullisemmaksi kuin $12^{\circ}-7^{\circ} \mathrm{C}$ :n vaihtolämpötila. Sen sijaan $24^{\circ} \mathrm{C}: \mathrm{n}$ tasa- ja $24^{\circ}-14^{\circ} \mathrm{C}: n$ vaihtolämpötila vaikuttivat haarojen muodostumiseen samalla tavoin.

Jauhosavikan lehtialaindeksi (LAI) muodostui kaikissa koelämpötiloissa erilaiseksi (taulukko 1). Se jäi pienimmäksi lämpötilan ollessa kautta vuorokauden $24^{\circ} \mathrm{C}$. Viileämmän yölämpötilan $\left(14^{\circ} \mathrm{C}\right)$ vaikutuksesta LAI kohosi jonkin verran ja muodostui suurimmaksi, kun lämpötila oli ympäri vuorokauden $12^{\circ} \mathrm{C}$. Yölämpötilan laskeminen tästä 7 asteeseen alensi lehtialaindeksiä merkitsevästi. Vuorokauden aikana tapahtuvan lämpötilan vaihtelun merkitys jauhosavikan lehtialaindeksin kehittymisessä ei ilmeisesti ollut yhtä suuri kuin lämpötilatason merkitys.

Taulukko 1. Lämpötilan vaikutus jauhosavikan lehtialaindeksiin (LAI) sekä lehtialan ja lehtien painon väliseen suhteeseen $(\mathrm{L}: \mathrm{P})$.

Table 1. Effect of temperature on the leaf area index (LAI) and the leaf area: leaf weight ratio (L:P) in C. al bu $m$.

\begin{tabular}{ccc}
\hline $\begin{array}{c}\text { Lämpötila } \\
\text { Temperature }{ }^{\circ} \mathrm{C}\end{array}$ & LAI $\left.^{\mathbf{1}}\right)$ & L:P $\left.{ }^{\mathbf{1}}\right)$ \\
\hline 24 & $0.3^{\mathrm{a}}$ & $295^{\mathrm{bc}}$ \\
$24-14$ & $1.1^{\mathrm{b}}$ & $384^{\mathrm{c}}$ \\
12 & $5.6^{\mathrm{d}}$ & $241^{\mathrm{b}}$ \\
$12-7$ & $4.5^{\mathrm{c}}$ & $190^{\mathrm{a}}$
\end{tabular}

1) Samassa sarakkeessa olevat luvut, joiden yläindeksiin sisältyy sama kirjain, eivät poikkea merkitsevästi toisistaan.

1) The values which include the same letter in the same columns are not significantly different at the level of 0.05 .

Kun 5000 luxin valaistuksessa kasvaneitten jauhosavikoitten lehtien oli silmävaraisesti havaittu olevan ohuempia, mutta pinta-alaltaan laajempia kuin 16000 luxin valaistuksessa kasvaneitten, pyrittiin tätä ominaisuutta kuvaamaan laskemalla lehtialan suhde lehtien painoon (L:P). Tällöin ilmeni, että myös lämpötila muutti tuota suhdetta (taulukko 1). Kautta vuorokauden tasalämpötiloissa kasvaneitten jauhosavikoitten L:Psuhde ei poikennut merkitsevästi toisistaan. Sen sijaan L:P oli huomattavasti pienempi ts. lehdet paksumpia ja pinta-alaltaan pienempiä $12^{\circ}-7^{\circ} \mathrm{C}$ :n kuin $24^{\circ}-14^{\circ} \mathrm{C}$ :n vaihtolämpötilassa kasvaneissa jauhosavikoissa.

Tutkittujen lämpötilojen vaikutus jauhosavikan satoon ilmeni varsin selvänä, sillä kaikki seuraavien satojen väliset erot osoittautuivat tilastollisesti merkitseviksi:

$\begin{array}{lc} & \text { Sato/astia, suhdeluku } \\ 24^{\circ} \mathrm{C} & 8 \\ 24^{\circ}-14^{\circ} \mathrm{C} & 16 \\ 12^{\circ} \mathrm{C} & 110 \\ 12^{\circ}-7^{\circ} \mathrm{C} & 100\end{array}$


Jauhosavikan kuiva-ainesato pinta-alayksiköltä nousi voimakkaan vegetatiivisen kasvun ja hitaasti tapahtuneen kehityksen vuoksi alhaisissa koelämpötiloissa moninkertaiseksi korkeisiin verrattuna. Rehusadon kannalta $12^{\circ}$ ja $12^{\circ}-7^{\circ} \mathrm{C}: n$ lämpötilat olivat siten edullisempia kuin korkeammat koelämpötilat. Vuorokauden aikana tapahtuva lämpötilan vaihtelu vaikutti edullisesti sadon määrään silloin, kun päivälämpötila oli $24^{\circ} \mathrm{C}$, mutta vähensi satoa päivälämpötilan ollessa $12^{\circ} \mathrm{C}$. Lehtien osuus sadosta oli merkitsevästi pienempi korkeissa kuin alhaisissa koelämpötiloissa, mutta tasa- ja vaihtolämpötilat eivät siihen vaikuttaneet, kuten oheisesta asetelmasta ilmenee:

$\begin{array}{lc} & \text { Lehtien osuus sadosta } \\ 24^{\circ} \mathrm{C} & 24.4 \% \\ 24^{\circ}-14^{\circ} \mathrm{C} & 23.1 \% \\ 12^{\circ} \mathrm{C} & 36.3 \% \\ 12^{\circ}-7^{\circ} \mathrm{C} & 36.7 \%\end{array}$

Valaistuksen vaikutus. Lämpötilan ollessa $24^{\circ}$ ja $24-14^{\circ} \mathrm{C}$ kehittyivät voimakkaammassa ja heikossa valaistuksessa kasvaneet jauhosavikat kukkimiseensa saakka jokseenkin yhtä nopeasti. Kukinnan päätyttyä hidastui jauhosavikoitten kehitys 5000 luxin valaistuksessa. Niinpä niiden siementen kehittyminen oli havaittavissa $24^{\circ} \mathrm{C}$ :ssa noin 8 vrk ja $24^{\circ}-14^{\circ} \mathrm{C}$ :ssa noin 20 vrk myöhemmin kuin 16000 luxin valaistuksessa kasvaneissa yksilöissä. Alhaisissa koelämpötiloissa $\left(12^{\circ}, 12^{\circ}-7^{\circ} \mathrm{C}\right)$ jauhosavikan kehitys oli koko ajan hitaampaa heikossa kuin voimakkaammassa valaistuksessa. Esimerkiksi yksilöitten haarautuminen alkoi 5000 luxin valaistuksessa noin 20 vrk ja kukinta noin 27 vrk myöhemmin kuin 16000 luxin valaistuksessa.

Haarojen lukumäärä yksilöä kohti oli suurempi voimakkaammassa kuin heikossa valaistuksessa kasvaneissa jauhosavikoissa. Valaistuksen ollessa 16000 luxia niihin kehittyi keskimäärin 7.3 haaraa, mutta 5000 luxin valaistuksessa vain puolet siitä eli 3.6 $\mathrm{kpl}$.

Valaistuksen voimakkuudella ei ollut merkitsevää vaikutusta lehtialaindeksiin. Sen sijaan heikossa valaistuksessa jauhosavikoitten L:P oli yli kaksinkertainen voimakkaammassa valaistuksessa kasvaneisiin yksilöihin verrattuna:

$\begin{array}{lrl} & \text { L:P } \\ \text { Valaistus } & 16000 \text { luxia } & 172^{\mathrm{a}} \\ \text { Valaistus } & 5000 \text { luxia } & 383^{\mathrm{b}}\end{array}$

Heikossa valaistuksessa jauhosavikat olivat jo silmävaraisesti arvostellen selvästi hennompia ja pienempiä kuin voimakkaamman valaistuksen saaneet yksilöt. Näiden keskimääräinen yksilönpaino oli $3.8 \mathrm{~g}$, kun heikossa valaistuksessa kasvaneet yksilöt painoivat vain $0.8 \mathrm{~g}$. Niinpä 16000 luxin valaistuksessa kehittynyt jauhosavikan kokonaissatokin oli $16.0 \mathrm{~g}$ astiaa kohti, mutta jäi 5000 luxin valaistuksessa 6.2 grammaan.

Lehtien osuus jauhosavikkasadosta 16000 luxin valaistuksessa oli $29.2 \%$ ja 5000 luxin valaistuksessa $31.1 \%$. Pienuudestaan huolimatta ero oli tilastollisesti luotettava 0.05 :n varmuudella.

Kasvuston tiheyden vaikutus. Kasvuston tihentymisen vaikutus jauhosavikan haarojen lukumäärään ilmeni samansuuntaisena kaikissa koejäsenissä, joten kuvassa 1 on esitettynä ainoastaan koko aineistoa kuvaava käyrä. Kun kasvutiheys lisääntyi, pieneni 


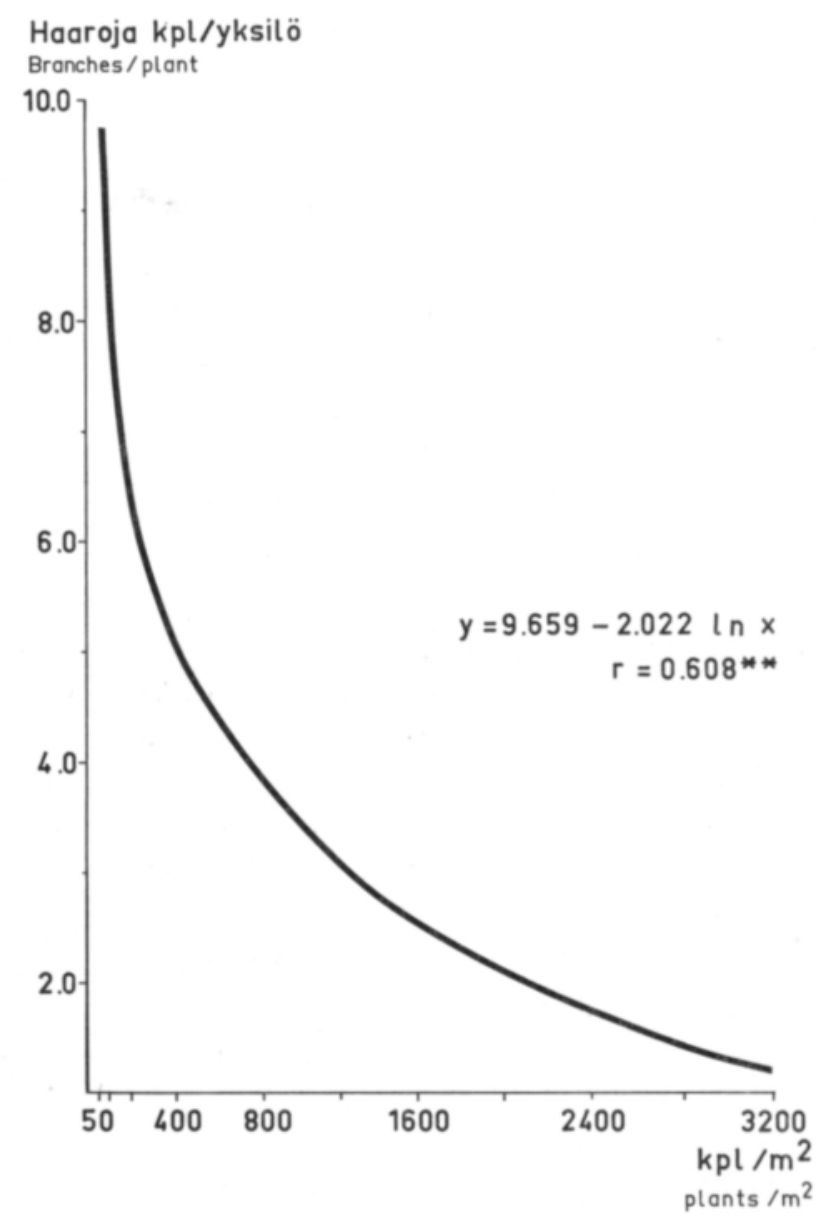

Kuva 1. Kasvuston tiheyden vaikutus jauhosavikan haarojen lukumäärään.

Fig. 1. Effect of plant density on the number of branches in C. album.

jauhosavikkayksilöitten haarojen lukumäärä. Sen kuvaamiseen soveltui viisi regressiokäyrää melko hyvin korrelaatiokerrointen vaihdellessa $-0.608--0.551$. Kuvaajista paras oli muotoa $\mathrm{y}=9.659-2.022 \ln \mathrm{x}$. Siitä ilmenee, että haarojen lukumäärä väheni jyrkimmin kasvuston tihentyessä 50:stä 400 yksilöön neliömetriä kohti. Kokeen päättyessä oli harvimman kasvuston yksilöissä keskimäärin 9.2 haaraa, mutta tiheimmässä vain 1.2 haaraa yksilöä kohti.

Jauhosavikan lehtialaindeksin (LAI) muuttumista tiheyden kasvaessa kuvasi erittäin hyvin regressiokäyrä, jonka yhtälö oli $\mathrm{y}=1.809+0.472 \ln \mathrm{x}$ (kuva 2). Kuvaaja osoittaa, että jauhosavikan yksilömäärän lisääntyessä pinta-alayksikköä kohti LAI suureni aluksi jyrkästi. Kun yksilôitten lukumäärä kohosi yli $400 \mathrm{kpl} / \mathrm{m}^{2}$, LAI kasvoi edelleen, mutta erot kasvustojen välillä eivät olleet yhtä huomattavat kuin harvemmissa kasvustoissa. 


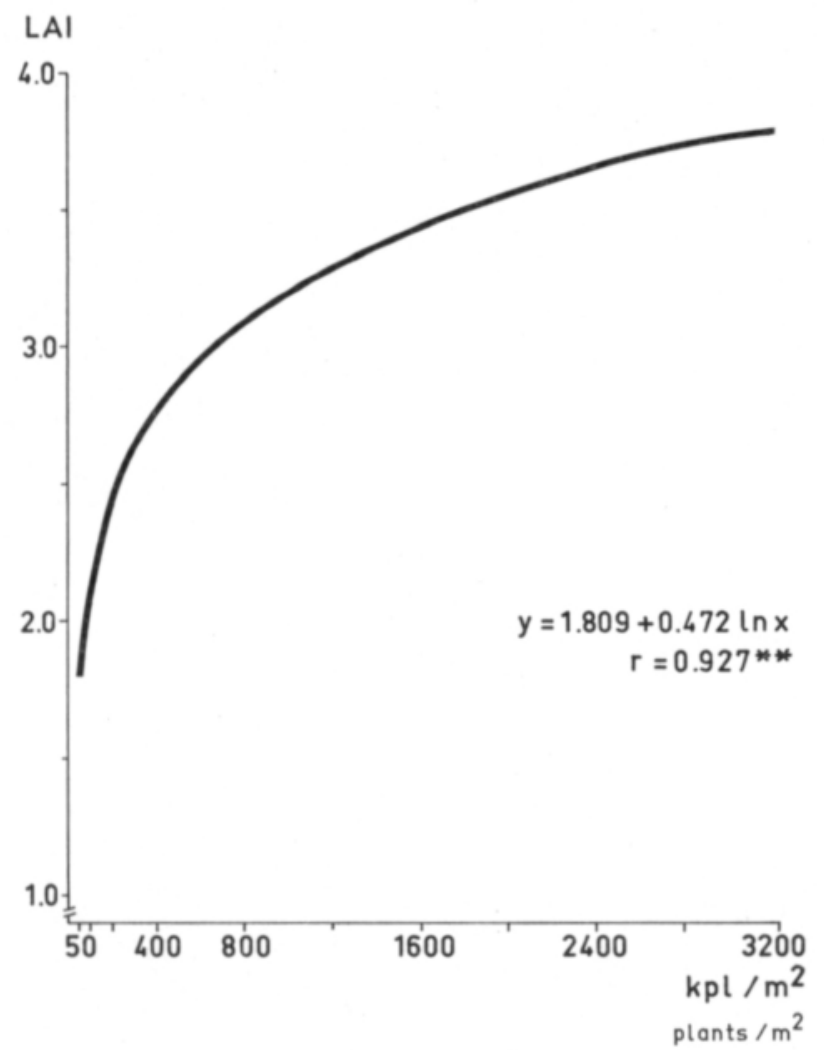

Kuva 2. Kasvuston tiheyden vaikutus jauhosavikan lehtialaindeksiin (LAI).

Fig. 2. Effect of plant density on the leaf area index (LAI) in C. album.

Jauhosavikan satokäyrän muoto kasvutiheyden lisääntyessä vaihteli lämpötilasta ja valaistuksen voimakkuudesta riippuen. Kun lämpötila molemmissa valaistuksissa oli $24^{\circ}$ ja heikossa valaistuksessa $24^{\circ}-14^{\circ} \mathrm{C}$, nousi jauhosavikan sato lineaarisesti yksilöitten lukumäärän lisääntyessä pinta-alayksiköllä (kuvat 3 ja 4). Sen sijaan 16000 luxin valaistuksessa $24^{\circ}-14^{\circ} \mathrm{C}: n$ vaihtolämpötilassa sadon muutoksia ilmensi parhaiten logaritminen funktio $\mathrm{y}=3.078+1.947 \ln \mathrm{x}$ (kuva 3 ). Se osoittaa sadon nousevan voimakkaasti kasvien lukumäärän lisääntyessä 50 :stä 400 yksilöön neliömetriä kohti. Tiheyden lisääntyessä edelleen sadon nousu hidastui kilpailun rajoittaessa kasvua.

Jauhosavikan vegetatiivinen kasvu oli erilaista alhaisessa kuin korkeassa lämpötilassa. Yölämpötilan alentaminen 16000 luxin valaistuksessa $24^{\circ} \mathrm{C}$ :sta $14^{\circ} \mathrm{C}$ :ksi voimisti vegetatiivista kasvua ja hidasti vastaavasti kehitystä aiheuttaen tällöin huomattavasti korkeamman sadon muodostumisen kuin $24^{\circ}$ C:n tasalämpötilassa erityisesti kasvustoissa, 
188

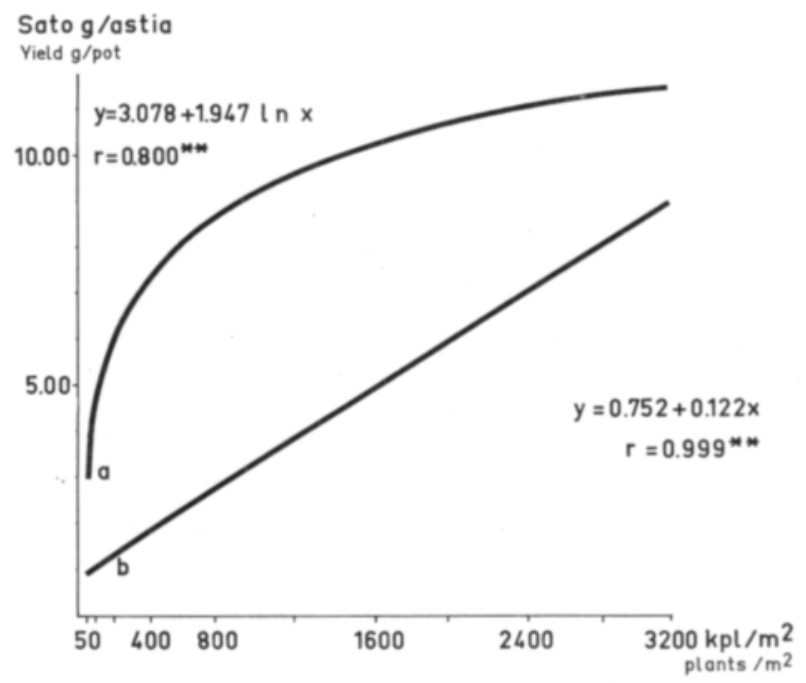

Kuva 3. Lämpötilan ja kasvuston tiheyden vaikutus jauhosavikan satoon valaistuksen voimakkuuden ollessa 16000 luxia. $\mathrm{a}=24^{\circ}-14^{\circ} \mathrm{C}, \mathrm{b}=24^{\circ} \mathrm{C}$.

Fig. 3. Effect of temperature and plant density on the yield of C. a lbum at light intensity of 16000 lux. $a=24^{\circ}-14^{\circ} \mathrm{C}, b=24^{\circ} \mathrm{C}$.

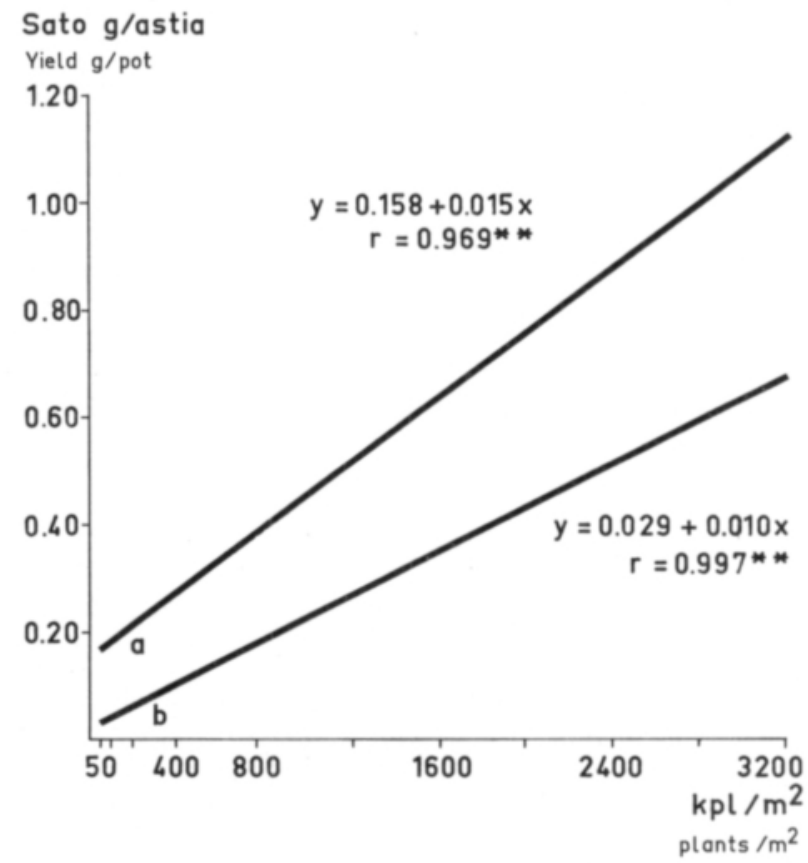

Kuva 4. Lämpötilan ja kasvuston tiheyden vaikutus jauhosavikan satoon valaistuksen voimakkuuden ollessa 5000 luxia. a $=24^{\circ}-14^{\circ} \mathrm{C}, \mathrm{b}=24^{\circ} \mathrm{C}$.

Fig. 4. Effect of temperature and plant density on the yield of $C$. a l b u $m$ at light intensity of 5000 lux. $a=24^{\circ}-14^{\circ} \mathrm{C}$, $b=24^{\circ} C$. 
joiden tiheydet olivat $200-1600 \mathrm{kpl} / \mathrm{m}^{2}$ (kuva 3). Sen sijaan 5000 luxin valaistuksessa yölämpötilan alentaminen lisäsi kasvien satoa samoissa tiheyksissä vain vähän.

Alhaisissa koelämpötiloissa $\left(12^{\circ}, 12^{\circ}-7^{\circ} \mathrm{C}\right)$ valaistus vaikutti satokäyrän muotoon enemmän kuin vaihto- tai tasalämpötila. Useista tutkituista funktioista soveltui 16000 luxin valaistuksessa $12^{\circ}$ ja $12^{\circ}-7^{\circ} \mathrm{C}$ :n lämpötiloissa parhaiten kuvaamaan jauhosavikan sadon muuttumista kasvutiheyden lisääntyessä parabeli, jonka regressioyhtälö oli ln y = $3.267+0.198(\ln \mathrm{x})-0.034(\ln \mathrm{x})^{2}$, joskaan korrelaatio ei ollut varsin korkea (kuva 5$)$. Sato nousi tällöin erittäin voimakkaasti kasvutiheyden lisääntyessä $800 \mathrm{yksilöön} / \mathrm{m}^{2}$

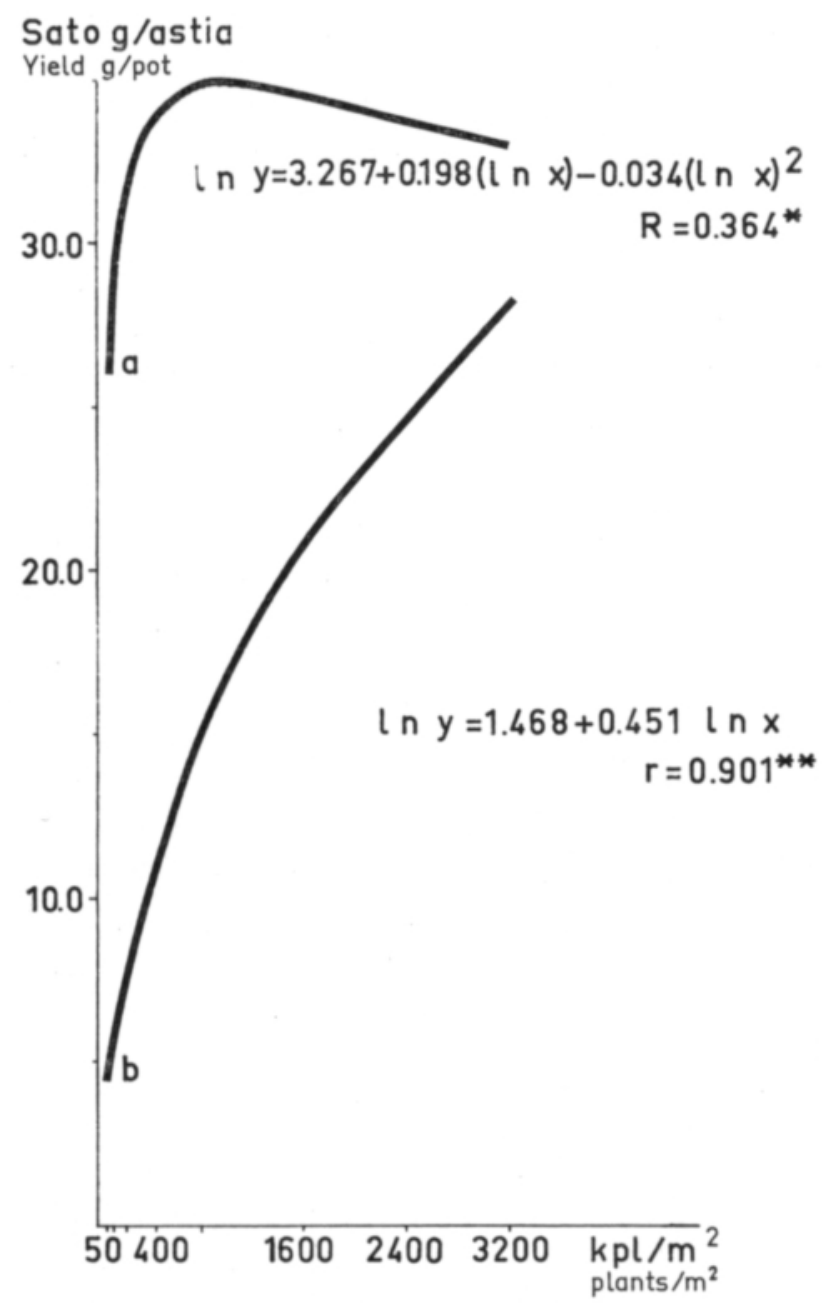

Kuva 5. Valaistuksen ja kasvuston tiheyden vaikutus jauhosavikan keskimääräiseen satoon $12^{\circ} \mathrm{C}$ ja $12^{\circ}-7^{\circ} \mathrm{C}: \mathrm{n}$ lämpötiloissa. $\mathrm{a}=$ valaistus 16000 luxia, $\mathrm{b}=$ valaistus 5000 luxia.

Fig. 5. Effect of light intensity and plant density on the average yield of $\mathrm{C}$. a l b u m at temperatures of $12^{\circ} \mathrm{C}$ and $12^{\circ}-7^{\circ}$ C. $a=16000$ lux, $b=5000$ lux. 
saakka ja alkoi tämän jälkeen lievästi laskea. Kyseisissä lämpötiloissa ja valaistuksen ollessa riittävän voimakas vegetatiivinen kasvu kohotti satoa erityisen huomattavasti harvoissa kasvustoissa, joissa rehevöitymiselle oli mahdollisuuksia. Yksilöitten rehevä kasvu aiheutti kuitenkin tiheimmissä kasvustoissa ankaran kilpailun, jonka vaikutuksesta sato jäi hiukan pienemmäksi kuin optimikasvutiheydessä, joka tässä tapauksessa oli $800 \mathrm{kpl} / \mathrm{m}^{2}$.

Samoissa lämpötiloissa 5000 luxin valaistuksessa kuvasi sadon kehittymistä parhaiten kauttaaltaan jyrkästi nouseva regressiokäyrä, jonka yhtälö oli ln $\mathrm{y}=1.468+0.451$ ln x (kuva 5). Sato kasvoi siten erittäin voimakkaasti kasvuston tiheyden lisääntyessä, mutta käyrän lievä kaartuminen oikealle osoittaa kasvustossa esiintyneen myös yksilöitten välistä kilpailua, joka jonkin verran hillitsi kasvua.

Lehtien osuus jauhosavikkasadosta oli jokseenkin samansuuruinen kaikissa tiheyksissä.

\section{Tulosten tarkastelu}

Lämpötila säätelee kasvua vaikuttamalla kaikkiin kasvin aineenvaihduntatoimintoihin. Nämä kiihtyvät korkeissa lämpötiloissa ja seurauksena on koko kasvutapahtuman nopeutuminen. Jo aikaisemmissa tutkimuksissa (ERvı̈ 1972) todettiin korkean lämpötilan $\left(24^{\circ} \mathrm{C}\right)$ jouduttavan jauhosavikan kehitystä, ja sama ilmiö oli havaittavissa myös nyt selostettavissa kokeissa. Sen sijaan oli yllättävää, että jauhosavikan reproduktiivinen kehitys estyi kukinnan jälkeen molemmissa alhaisissa koelämpötiloissa. Kirjallisuuden mukaan (mm. HARder ym. 1965, BlAck ja EdELMAN 1970) tiedetään vielä hyvin vähän prosesseista, jotka liittyvät lämpötilan kasvua säätelevään vaikutukseen. Kasvun äärilämpötilojen lyhytaikaisenkin vaikutuksen on kuitenkin todettu aiheuttaneen muutoksia monien kasvien kehityksenkulussa ja kasvussa. Niinpä mm. Beta- ja Brassica-sukujen kaksivuotiset kasvit sekä useat sarjakukkaiset eivät kuki, vaan saattavat jäädä vuosikausiksi vegetatiiviselle asteelle, elleivät joudu alttiiksi alhaisille lämpötiloille. Sitäpaitsi kasvit voivat jossakin kehitysvaiheessaan olla tavallista herkempiä lämpötilan vaikutukselle. Vaikka jauhosavikka on lähes kaikkialle maailmassa levinnyt kosmopoliitti, on mahdollista, että se olisi jossain määrin lämpöä vaativa laji. Tähän viittaisi Hultenin (1971) maininta, että jauhosavikka esiintyy harvinaisena havumetsävyöhykkeen pohjoispuolella. Kun jauhosavikka ei muodostanut siemeniä $12^{\circ}$ ja $12^{\circ}-7^{\circ} \mathrm{C}$ :n lämpötiloissa, mutta niitä alkoi kehittyä $24^{\circ}-14^{\circ} \mathrm{C}$ :ssa, on otaksuttavissa, että kasvit olisivat mahdollisesti tarvinneet täydellisesti kehittyäkseen myös $12^{\circ} \mathrm{C}$ korkeampia lämpötiloja edes lyhytaikaisesti kasvuaikanaan tai erityisesti jollakin tietyllä kehitysasteella.

Vaikuttamalla jauhosavikan vegetatiiviseen kasvuun lämpötila samalla aiheutti muutoksia lehtialaindeksissä. Korkeassa lämpötilassa $\left(24^{\circ} \mathrm{C}\right)$ kasvien lehdet olivat pieniä, joten myös LAI jäi alhaiseksi (taulukko 1). Kun lämpötilaa alennettiin osaksikin vuorokautta, nousi LAI. Toisaalta lämpötilan alentaminen yöksi silloin, kun päivälämpötila oli vain $12^{\circ} \mathrm{C}$, hidasti ilmeisesti yksilöitten vegetatiivistakin kasvua siinä määrin, että myös LAI jäi pienemmäksi kuin $12^{\circ} \mathrm{C}$ :n tasalämpötilassa.

Lämpötila vaikutti myös huomattavassa määrin jauhosavikan pinta-alayksiköltä tuottaman kuiva-ainesadon määrään. Pienimmäksi se jäi lämpötilan ollessa $24^{\circ} \mathrm{C}$ (asetelma s. 184), sillä kehitys oli tällöin niin nopeata ja dissimilaatiotappiot todennäköisesti suurehkoja, että vegetatiivista rehevöitymistä ei ehtinyt tapahtua. Kasviyksilöt jäivät pieniksi ja niihin muodostui vain vähän haaroja sekä pieniä lehtiä. Kuten aikaisemminkin 
todettiin (ERvıö 1972), on myös mahdollista, että fytotronien suurin valon voimakkuus 16000 luxia ei ollut korkeaan lämpötilaan nähden täysin riittävä runsaan sadon tuottamiseksi. Kun lämpötila alennettiin yöksi, nousi sato $100 \%$, mikä ilmeisesti johtui ainakin osaksi dissimilaatiotappioiden pienenemisestä. Sitäpaitsi on todettu useiden viileän ilmaston kasvien kasvavan paremmin yölämpötilan ollessa päivälämpötilaa alhaisempi (Claudsen ym. 1948, Lundegårdh 1957). Yölämpötilan ollessa fytotroneissa vain $7^{\circ} \mathrm{C}$ lienevät jauhosavikan elintoiminnat hidastuneet siinä määrin, että vegetatiivinen kasvukin heikentyi, ja sato jäi sen vuoksi jonkin verran alhaisemmaksi kuin lämpötilan ollessa kautta vuorokauden $12^{\circ} \mathrm{C}$.

Valaistuksen vaikutus kasvuun ilmenee kahdella tavalla, joista toinen liittyy fotosynteesiin, toinen säätelee kasvin morfologista muovautumista, kuten lehtien kokoa ja versojen pituutta. Valon puute hidastaa kehitystä ja kasvua, sillä heikossa valaistuksessa nettoassimilaatio jää pieneksi varsinkin lämpötilan ollessa korkea. Niinpä useita kasvilajeja koskevissa tutkimuksissa (mm. Went 1957, Palmer 1958, Håkansson 1969, NösBERGER 1971) on sadonalennus heikossa valaistuksessa ollut ilmeinen. Fytotroneissa 5000 luxin valaistus vastasi suunnilleen valaistuksen intensiteettiä tiheydeltään normaalissa vehnäkasvustossa tähkimisen aikaan, kun taas 16000 luxia vastannee valaistuksen voimakkuutta suhteellisen harvassa kasvustossa samana ajankohtana. Näistä 5000 luxin valaistus aiheutti jauhosavikassa muutoksia, joita heikon valaistuksen on edellä todettu aiheuttavan. Sen kehitys oli hitaampaa ja haarojen lukumäärä yksilöä kohti sekä sato jäivät pienemmiksi 5000 kuin 16000 luxin valaistuksessa (vrt. s. 185). Sitäpaitsi sadon alennus oli suhteellisesti suurempi korkeissa kuin alhaisissa koelämpötiloissa. Jauhosavikan lehtien pinta-alan ja painon välinen erilainen suhde 16000 ja 5000 luxin valaistuksissa osoitti heikossa valaistuksessa kasvaneitten yksilöitten pyrkineen laajentamaan lehtialaansa kaikin tavoin.

Lämpötila ja valaistus vaikuttivat kasvumalliin, joka kuvasi jauhosavikan sadon muuttumista kasvutiheyden lisääntyessä. Oloissa, joissa yksilöt jäivät pieniksi (kuva 3 ja 4) sato nousi lineaarisesti yksilömäärän lisääntyessä pinta-alayksiköllä, eikä tiheissäkään kasvustoissa ilmennyt satoa rajoittavaa kilpailua. Lämpötilan ollessa $24^{\circ}-14^{\circ} \mathrm{C}$ (kuva 4), yksilöt rehevöityivät 16000 luxin valaistuksessa siinä määrin, että sato nousi harvoissa kasvustoissa voimakkaasti. Kasvuston tihentyessä yksilöt kuitenkin joutuivat kilpailemaan keskenään yhä ankarammin, mikä puolestaan hillitsi kasvua ja pienensi sadon lisäystä tiheimmissä kasvustoissa. Molemmissa alhaisissa koelämpötiloissa $\left(12^{\circ}\right.$, $12^{\circ}-7^{\circ} \mathrm{C}$ ) jauhosavikat kasvoivat voimakkaasti rehevöitymisen ollessa kuitenkin runsaampaa ja kilpailun vastaavasti ankarampaa 16000 kuin 5000 luxin valaistuksessa. Sen vuoksi myös sadon nousu tiheimmissä kasvustoissa voimakkaammassa valaistuksessa lakkasi kokonaan, kun yksilömäärä lisääntyi yli $800 \mathrm{kpl} / \mathrm{m}^{2}$, mutta heikossa valaistuksessa jatkui edelleen tiheimpään kasvustoon saakka.

\section{Tiivistelmä}

Edellä selostettujen tutkimusten tarkoituksena oli selvittää erilaisten lämpötilojen sekä valaistuksen voimakkuuden vaikutusta jauhosavikan sadon muuttumiseen eri kasvutiheyksissä. Tulokset osoittivat jauhosavikan kehittyneen nopeammin ja muodostaneen vähemmän haaroja yksilöä kohti korkeissa $\left(24^{\circ}, 24^{\circ}-14^{\circ} \mathrm{C}\right)$ kuin alhaisissa $\left(12^{\circ}, 12^{\circ}-\right.$ 
$7^{\circ}$ ) koelämpötiloissa. Sen lehtialaindeksi (LAI) sekä kuiva-ainesato jäivät pienimmiksi $24^{\circ} \mathrm{C}$ :ssa, kohosivat jonkin verran $24^{\circ}-14^{\circ} \mathrm{C}$ :ssa, olivat suurimmillaan $12^{\circ} \mathrm{C}$ :ssa ja laskivat edelliseen verrattuna, kun lämpötila oli $12^{\circ}-7^{\circ} \mathrm{C}$.

Jauhosavikan kehitys oli nopeampaa ja haarojen lukumäärä/yksilö suurempi 16000 kuin 5000 luxin valaistuksessa. Heikossa valaistuksessa muodostuneet lehdet olivat painoonsa nähden laajempia pinta-alaltaan kuin voimakkaammassa valossa kehittyneet. Jauhosavikan sato pinta-alayksiköltä nousi huomattavasti korkeammaksi, mutta lehtien osuus sadosta jäi pienemmäksi 16000 kuin 5000 luxin valaistuksessa.

Jauhosavikan haarojen lukumäärä yksilöä kohti väheni jyrkästi kasvutiheyden lisääntyessä 50:stä 400 yksilöön $/ \mathrm{m}^{2}$. LAI taas kasvoi voimakkaasti samaan kasvutiheyteen saakka, mutta sitä tiheämmissä kasvustoissa nousu hidastui. Lämpötila ja valaistuksen voimakkuus vaikuttivat huomattavassa määrin kasvumalliin, joka kuvasi jauhosavikan sadon muutoksia kasvutiheyden lisääntyessä (kuvat 3-5). Oloissa, joissa yksilöt jäivät pieniksi, sato nousi lineaarisesti, mutta vegetatiivisen kasvun ollessa voimakasta sadon nousu hidastui tiheissä kasvustoissa yksilöitten välisen kilpailun vaikutuksesta.

\section{KIRJALLISUUTTA}

Black, M. \& Edelman, J. 1970. Plant growth. 193 p. London.

Clausen, J., Keck, D. D. \& Hiesey, W. M. 1948. Experimental studies on the nature of species. III. Environmental responses of climatic races of Achillea. Carnegie Inst. Wash. Publ. 520: 1-129.

ERviö, L-R. 1971. The effect of intra-specific competition on the development of Chenopodium album L. Weed Res. 11: 124-134.

ERvıö, L-R. 1972. Kasvuston tiheyden ja lämpötilan vaikutus jauhosavikan (Chenopodium album L.) ja sen sadon kehittymiseen. Maatal.tiet. Aikak. 44:29-40.

Harder, R., Schumacher, W., Firbas, F. \& Denffer, D. von 1965. Strasburger's textbook of botany. 846 p. Suffolk.

Hulten, E. 1971. Atlas över växternas utbredning i Norden. 531 p. Stockholm.

HÅkansson, S. 1969. Experiments with Agropyron repens (L.) Beauv. VII. Temperature and light effects on development and growth. Lantbr.högsk. Ann. 35: 953-987.

LuNDEg ÅrdH, H. 1957. Klima und Boden. 579 p. Jena.

Nösberger, J. 1971. Einfluss der Bestandesdichte auf die Ertragsbildung bei Mais. Z. Acker-, Pfl.bau 133: 215-232.

Palmer, J. H. 1958. Sudies in the behaviour of the rhizome of Agropyron repens (L.) Beauv. I. The seasonal development and growth of the parent plant and rhizome. New Phytol. 57: 145-159.

WENT, F. W. 1957. The experimental control of plant growth. 343 p. Waltham.

Wiggans, R. G. 1939. The influence of space and arrangement on the production of soybean plants. J. Amer. Soc. Agronomy 31: 314-321. 